\title{
Investigating contact-induced T cell polarisation at virological synapses
}

\author{
Shimona Starling ${ }^{*}$, Elisabetta Groppelli, Alice Len, Clare Jolly \\ From Frontiers of Retrovirology: Complex retroviruses, retroelements and their hosts \\ Cambridge, UK. 16-18 September 2013
}

\section{Background}

Human Immunodeficiency Virus Type-1 (HIV-1), the main causative agent of Acquired Immunodeficiency Syndrome (AIDS) is a major global health problem. Cell-cell spread of HIV-1 between CD4 T cells confers many advantages including more rapid infection kinetics, evasion of neutralising antibodies and cellular restriction factors, and may pose a barrier to eradicating HIV-1 from the host. HIV-1 cell-cell spread occurs at intercellular contacts called virological synapses (VS) at which HIV-1 preferentially assembles and buds. We have previously shown that the microtubule organising centre (MTOC) and associated organelles are polarised within the HIV-1 infected cell at the VS; however the causes and consequences of this are unknown.

\section{Materials and methods}

We have coupled immunofluorescence microscopy with functional virology and mutant $\mathrm{T}$ cell lines to investigate recruitment of cellular and viral proteins to the VS.

\section{Results}

We show that recruitment of the MTOC to the VS is triggered upon engagement of integrins on the HIV-1 infected cell and that HIV-1 infected T cells appear more prone to polarise. Our data implicate the integrin LFA-1 as an important component of this process. Time course analysis coupled with pharmacological inhibitors reveals that $\mathrm{T}$ cell polarisation to the VS is an active process, suggestive of localised synaptic signaling. In support of this, we find evidence for enriched phosphotyrosine staining at the VS.

\section{Conclusions}

LFA-1 engagement on HIV-1 infected cells plays a key role in triggering contact-induced $\mathrm{T}$ cell polarisation at

Division of Infection and Immunity, University College London, London, UK the VS. This provides further evidence that cell-to-cell spread at the VS is highly regulated.

Published: 19 September 2013

doi:10.1186/1742-4690-10-S1-P86

Cite this article as: Starling et al:: Investigating contact-induced T cell polarisation at virological synapses. Retrovirology 2013 10(Suppl 1):P86.
Submit your next manuscript to BioMed Central and take full advantage of:

- Convenient online submission

- Thorough peer review

- No space constraints or color figure charges

- Immediate publication on acceptance

- Inclusion in PubMed, CAS, Scopus and Google Scholar

- Research which is freely available for redistribution
() Biomed Central 